\title{
Management Emotion and Firm's Propensity of Strategic IT Investment
}

\author{
Nan (Tina) Wang \\ Eastern Illinois University \\ nwang@eiu.edu
}

\author{
Weijun Zheng \\ University of Wisconsin-Parkside \\ zheng@uwp.edu
}

\author{
Wenbo Zhang \\ McGill University \\ wenbo.zhang@mail.mcgill.ca
}

\begin{abstract}
Firm's propensity of strategic IT investment describes the tendency of firms to engage in different strategic roles of IT when IT investment decisions are made. Different from prior IS business value literature that has largely taken rational decision making for granted, this paper considers the irrational characteristics of firms' decision making and investigated the impacts of management emotion on firms' propensity of strategic IT investment. Based on 191 annual reports of 32 companies from three industries in a 6-year period (i.e., 2010-2015 fiscal year), we applied sentiment analysis to retrieve emotion tunes embedded in each report and analyzed their relationship with both the volume and the composition of three types of strategic IT signals (automate, informate and transform). Our results show that positive management emotion promotes firm's propensity of all types of strategic IT investments, and increase weights of informate and/or transform IT among all strategic IT investments. With positive management emotion, firms also show propensity of investing in strategic IT different from the industry's dominant IT strategic role.
\end{abstract}

\section{Introduction}

Firm's strategic IT investment is an investment decision that managers make regarding strategically deploying and developing IT assets and capabilities. It reflects managers' perception of IT's strategic roles in business value creation and signals firm's IT strategic direction to the markets. As firms' decisions on strategic IT investment are fundamental in the shaping of their information systems, it would be interesting and important to ask what factors are shaping those strategic IT investment decisions?

In financial markets, irrational psychological and emotional factors have often been found to derive financial investments from rational decision making (i.e., one that balance payoff and risk), and generate abnormal investment effects, e.g., overreaction, group behavior, the emergence of speculative bubbles, the excessive volatility of the stock market, and so on [1]. In comparison, evidences for the impacts of psychological and emotional factors on strategic IT investments have been rare in the IS literature. Despite earlier debates on why rational IT investments has not been paid off, many recent IS research attributes prior mixed results to research structure issues such as inadequate measurement and analysis methodologies [2, 3], time lags in measuring payoffs [4], and concludes that improvements can be made by carefully selecting sample size, data source, industry, dependent variables, the type of statistical analysis conducted, and cross sectional or longitudinal design, and etc. [5]. The implication of prior research is that rational IT investments will be paid off, but academia needs better research design to prove it.

In this research, we question the underlying rational decision maker assumption of firms in the existing IS literature on strategic IT investment in which managers, when facing highly uncertain strategic IT decisions, would prefer an investment with higher payoff and lower risk [6]. We argue that if management judgement can be influenced by emotion when making strategic IT investment, IT payoff may not be granted by the expected (normal) return out of rational decision making. Consequently, the irrationality of management decision can be responsible for mixed results in prior IT business value research. We held that IT strategic investment can reflect management emotion and generate unexpected (abnormal positive or negative) return. Our research question is thus: Whether and how can management emotion affect firms' strategic IT investment?

The rest of this paper will start with a review of related literature, followed by hypothesis development. Next the paper describes its research method and reports its hypothesis testing results. Last the paper gives discussion and conclusion.

\section{Literature Review}




\subsection{Emotion and investment decision making}

Emotion is used to specify discrete and intense though short-lived feelings towards an event, object, or a person [7]. Emotions are not limited to individual level and can represent a group or organizational level affective state [8-10]. In this paper, we focus on the overall emotion of firm's top management, or management emotion. To simplify the discussion, we will use positive (negative) emotion to refer to overall positive (negative) management emotion hereafter.

Emotion can affect investment decision making by preferential selection of information for processing. Literature notes that decision makers are inclined to react to and accept external information echoing to their internal emotions [11, 12]. Thus, individuals in positive emotional states try to preserve these positive emotions and to alter negative ones. As a result, individuals are more likely to reject options eliciting negative emotions and to accept options eliciting positive emotions [13]. Preferential selection of information can distort decision makers' judgement by enlarging the strength (intensity) of biased evidences and etiolate the weight or credibility of them [14]. Decision makers then can be misled to become overconfident in forecasting, or the opposite (lack of confidence) the outcomes of their decisions [14].

Emotion can also affect decision making through alternating strategies of information processing. It has been found that positive emotion triggers heuristic decision-making strategies that is characterized by topdown processing with heavy reliance on pre-existing knowledge structures [15]. Negative emotion activate systematic decision-making strategies that require relatively deep thoughts with more questions and doubts from bottom up on the existing information, rules, and knowledges [16-18]. If the decision to make is too complicated and its outcomes are too difficult to predict accurately, heuristics decision making strategies can help simplify the decision-making process and reduce decision costs and time, which may result in decisions that normally would not be made if they went through systematic analytic process.

Finally, emotion can affect decision making by shifting reference group applied to a decision. People tend to closely follow what others do and imitate others' move when make decisions for their own. In financial markets, investors were found to follow the main market participants [19]. In the IT field, herding behavior can cause technologically inefficient innovations to diffuse [20] or create barriers for efficient innovations to be adopted [21]. Individuals experiencing positive emotions tend to perceive a broader array of events and stimuli than persons experiencing negative emotions [22, 23], which let them be less likely to discount their own information/beliefs and imitate the others (Sun 2013). People under positive emotion often are more creative and proactive [24, 25], more willing to exploit future opportunities [26], and engage in entrepreneurship [27]. They are thus more likely to break away from the established reference group, and to think and act differently from the peers. Negative emotion, however, can enlarge people's need to obtain psychological safety and discourage independent cognation, hence, push people to stay with existing reference group when making decisions.

\subsection{Firm's propensity of strategic IT investment}

Firms can engage in different types of strategic IT investment depending on the purposes of IT use underlying the IT investment. Firm's propensity of strategic IT investment refers to the tendency of firms to engage in different strategic roles of IT when they make IT investment. Prior IS research has identified several types of firms' strategic IT investments propensity [28-30]. This paper adopts Zmud and colleagues [31]'s three-category schema for categorizing IT investment, as listed below:

- Automate-investing in IT to replace human manual work with automatic processes to improve work efficiency, speed, and productivity

- Informate-investing in IT to enable information exchange for the purpose of analysis, vertical or horizontal coordination, and control or empowerment of the other organizational layer

- Transform-investing in IT to fundamentally redefine business and/or industry practices, processes, and relationships for revenue growth and profitability

\subsection{IT and emotion signaling of annual reports}

To explore the roles of management emotion in firms' strategic IT investment, we used IT strategic signals and emotional tune embedded in firms' annual reports as measurements for firms' propensity of strategic IT investment and management emotion respectively.

Annual reports are reliable communicating accounts of a firm's behaviors and attitudes. Due to institutional requirements and managers' tendency to minimize surprises and mitigate adverse long-term effects on firm's financing ability in the capital markets, annual reports provide fairly comparable and stable sets of data over time [32, 33].

Prior literature shows that firms can use IT strategic signaling through annual reports to communicate their 
current and future IT capabilities and performance outcomes [31, 34, 35]. Signals regarding strategical investment and use of IT assets also indicate investors the expected marketplace impacts of IT and the dominant roles of IT in an industry. IT strategic signals therefore have often been used by investors to interpret and predict firms' IT strategic development paths and tendencies and by academia to study firms' IT investment behaviors [30, 31, 36-38].

Similarly, emotional tunes embedded in annual reports are deemed to reflect management emotion [39, 40]. Managers have greater flexibility when writing the text portion as compared to the number portion of the annual reports, and may carefully craft the text portion to influence readers' (e.g., stakeholders) expectations. Hence, the text portion of annual reports is important for understanding and inferring management behavior and strategic intent [41]. Compared to that in press releases, emotion embedded in annual reports may be less affected by discrete events during the yearly reporting period and more accurately reflect management emotion based on their perception of overall business.

\section{Hypothesis development}

Strategic IT investments are often very expensive and of long-term commitments, which inherit a great amount of risks due to the complexity of new information systems, the constraints of organizational context in IS deployment, the ease of successful IT innovations to be imitated by competitors, etc. [30, 42, 43]. Often firms' decisions on complex strategic IT investments come from not only grounded rational model but also management confidence, courage and vision etc. As reviewed earlier, management emotion has important roles in decision making process and thus is expected to influence firms' propensity of strategic IT investment. Figure 1 below gives our research conceptual model.

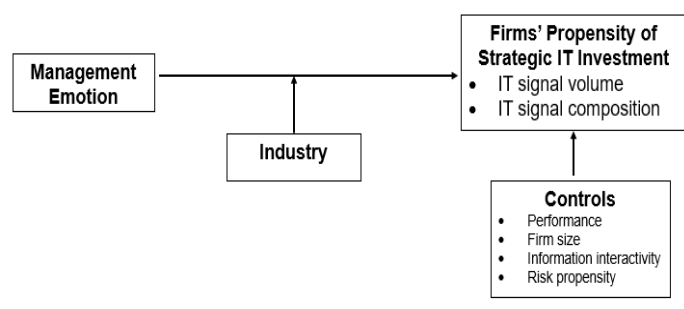

Figure 1. Research Model

First, as reviewed earlier, emotion can distort managers' judgement through preferential selection of information, which may result in managers experiencing positive emotions perceive firms' external environment more favorably than managers experiencing neutral or negative emotions [44, 45]. Specifically, positive emotion increases mangers' tendencies to engage in strategic IT investment as they are more optimistic about either future resource availability and/or future project outcomes. Negative emotion, in contrast, exaggerates managers' fear of uncertainty and hold their investment on strategic IT back. Note that the changes of firms' tendencies to engage in strategic IT investment under positive emotions are applicable to all types of strategic IT investment. This leads to our first set of hypotheses:

Hypothesis 1: Positive management emotion will promote the volume of firm's strategic IT investment signals

Hypothesis 1a: Positive management emotion will promote the volume of firm's automate IT investment signals

Hypothesis 1b: Positive management emotion will promote the volume of firm's informate IT investment signals

Hypothesis 1c: Positive management emotion will promote the volume of firm's transform IT investment signals

Second, management emotion may also affect the composition of firm's strategic IT investment due to decision making method selected under emotion. The complexity and difficulty in assessing investment value and outcome can let some strategic IT investments, for instance, transform IT and informate IT, unlikely get approved if they went through systematic evaluation. Transform IT deployments, in particular, are least likely to be undertaken during a systematic evaluation due to their heightened risk [46, 47], financial burden [48, 49], and likelihood of implementation abandonment [50]. In contrast, automate IT are relatively simple and easy to assess, thus more likely considered favorable by systematic decision strategies. As reviewed earlier, managers with positive emotions are more likely to apply heuristic decision strategies to complex decision problems such as transform and informate IT investment, which could help to lower the hurdles for those strategic IT investments being approved and increase their approval rates. Automate IT, however, is less likely going through heuristic evaluation and can keep its approval rates little changed. Consequentially, the proportion of transform and informate IT among all strategic IT investments will likely increase, while the proportion of automate IT will likely decrease. This produces our second set of hypotheses:

Hypothesis 2: Positive management emotion will shift the composition of firm's strategic IT investment signals 
Hypothesis 2a: Positive management emotion will decrease the proportion of automate IT among all strategic IT investment signals

Hypothesis 2b: Positive management emotion will increase the proportion of informate IT among all strategic IT investment signals

Hypothesis 2c: Positive management emotion will increase the proportion of transform IT among all strategic IT investment signals

Third, by shifting reference group applied to decision making, emotion can stimulate firms to invest in strategic IT that is different from their industry's dominant IT strategic roles. Those industry dominant IT strategic roles are shaped by distinctive industrylevel contexts within which IT deployments occur and become legitimate patterns in each industry's IT use. For example, transform IT investment is believed to be dominant in very dynamic industries (e.g., retail) whose business processes and product/service offerings are highly digitizable. Automate IT investment is more popular in relatively stable industries (e.g., metal) whose business processes and product/service offerings are either difficult to digitize or for whom digitization is difficult to justify [31]. Informate IT investment is particularly welcome in industries (e.g., financial) with moderately dynamic and digitizable business processes and product/service offerings where IT is primarily exploited in archiving, analyzing, disseminating, and applying digitized data to inform stakeholders' actions [31]. It is evident that most firms tend to engage in limited IT innovation only and prefer to adopt technologies already proven effective by industry peers [31], which makes it difficult for firms to invest in strategic IT different from industry's dominant IT strategic roles. However, positive emotion may broaden managers' scope of attention, help them take in more positive information, and promote other complex cognitive functions such as global thinking and novel and creative thinking (e.g., seeing the forest rather than the trees) [51-55]. Consequently, management with positive emotions are more likely to seek IT investments different from industry's dominant IT strategic roles. Negative emotions, on the hand, discourage managers' exploration of IT opportunities and make them stick to conventional reference group in strategic IT investments. Hence:

Hypothesis 3: Positive management emotion will promote propensity of strategic IT investment different from its industry's dominant IT strategic roles.

\section{Research methodology}

\subsection{Data collection}

To test our model, we followed the theoretical sampling approach to collect data [56]. The theoretical sampling approach ensures theoretical constructs adequately represented in the sample and has been successfully applied in prior IT signaling research [31].

The industries selected for our research are metal, retail and financial. Each of those industries was examined by Zmud and colleagues [31] and thought to have a dominant industry IT strategic role, i.e., automate (metal), informate (financial), and transform (retail) respectively, consistent with the [57] classifications.

Using the COMPUSTAT database, we generated our sample set consisted of top- and bottom-five performing companies, based on three measures of firm performance (i.e., return on asset, return on investment, and equity per share), from each of the three industries above in a 6-year period (i.e., 20102015 fiscal year). This resulted in a total of $32^{1}$ companies - the list of companies is not provided here due to space limitation and is available upon request. For each of the companies, we found their annual reports (form 10-K) for 2010-2015 fiscal years from SEC website (sec.gov/edgar). We had a total of $191^{2}$ annual reports downloaded from SEC website.

\subsection{Construct measurement}

Management emotion. To measure management emotion, the independent variable in this research, we conducted sentiment analysis on the 191 annual reports using the software Pysentiment, which contains the Loughran \& McDonald Master Dictionary. This dictionary was developed specifically for sentiment analysis on annual reports and has been used in existing research (see [39] for a review). The sentiment analysis produced an overall emotion score, as explained below, for each of the 191 annual reports.

The emotion score is calculated by comparing the text of each report to the Loughran \& McDonald Master Dictionary. This process counts the positive and negative words in the text and calculates the emotion score according to the definition below [58]. Emotion score may range from -1 to 1 . Positive (negative) emotion score means that the overall sentiment tone of the annual report is positive (negative); and the higher the absolute number of the emotion score, the stronger the emotion intensity.

\footnotetext{
1 There were some equally performing companies, resulting in 11 (rather than 10) companies from the metal industry and 11 companies from the retail industry.

2 One company went initial public offering (IPO) in 2011 and its annual report for 2010 was not available from SEC website.
} 


$$
\text { emotion score }=\frac{\text { positive count }- \text { negative count }}{\text { positive count }+ \text { negative count }}
$$

Firms’ propensity of IT strategic investment. We used both IT signal volume (i.e., the number of automate/informate/transform IT investment signals) and IT signal composition (i.e., the percentage of each type among all IT investment signals) in annual report to measure firm's propensity of IT strategic investment, the dependent variable in this research.

Two primary researchers independently coded firms' annual reports at the sentence level, and met for finalized codes, with reference to the coding schema of Zmud et al [31]. Sections coded in firms' annual reports include the letter to shareholders and other materials prior to management's discussion and analysis of financial data. Inter-coder reliability based on Cohen's Kappa is 0.87 , reflects “almost perfect" (0.81-1.0) agreement [59].

Coding of annual reports mentioned above produced a count of IT signals (or IT signal volume), associated with each type of IT investment for each firm in each fiscal year. After counting the IT signal volume, we calculated IT signal composition, i.e., the percentage of automate/ informate/transform IT among all strategic IT investment signals.

Control variables. Based on the existing literature [31, 60], we included the following control variables: industry (i.e., metal, financial, retail), three measures of firm performance (i.e., return on asset, return on investment, and equity per share), firm size (i.e., the number of employees), information interactivity (i.e., the average number of lines in firms' annual reports), and two measures of risk propensity (i.e., debt-toequity and Torbin’s Q).

\subsection{Data analysis and results}

Before analysis, data is standardized across the whole sample. The construct, firms' propensity of IT strategic investment has two types of measurement, i.e., count data and percentage serving as dependent variables. Different analysis methods were applied through SPSS for each dependent variable Specifically, for IT signal volume (i.e., count data), we applied a generalized linear model (GLZ) analysis with negative binomial distribution [61], which is preferred over Poisson distribution as the data shows overdispersion (i.e., the variance of the count data is much higher than the mean); for IT signal composition (i.e., automate percentage, informate percentage, and transform percentage), we applied multivariate regressions. Since annual reports are summaries of firms' current year activities $(\mathrm{t}=1)$, emotion score from prior year $(\mathrm{t}=0)$ annual reports was used as independent variable in equation to examine emotion influence on firms' current year ( $\mathrm{t}=1)$ IT signaling behaviors. Results are given below:

Hypothesis 1 argues that positive management emotion will increase the volume of all types of strategic IT investment, specifically, positive management emotion will increase the number of automate (H1a), informate (H1b), and transform (H1c) IT investments. Results, as shown in columns 2-4 of Table 1, suggest that management emotion has a positive impact on automate and informate IT investments, but not on transform IT investment. Hence, H1a and H1b are supported, but H1c is not. Overall, positive emotion increases the volumes of all IT signals, H1 is thus supported.

Hypothesis 2 argues that positive emotions will decrease the proportion of automate IT investment (H2a), and increase the proportions of informate (H2b) and transform (H2c) IT among all strategic IT investments. Results of multivariate analyses are shown in columns 5-7 Table 2 below. The significant and negative influence of emotion on automate IT percentage in results suggests that positive emotions decrease the percentage of automate IT investment among all, supporting H2a; the significant and positive influence of emotion on informate IT percentage suggests that positive emotions increase the percentage of informate IT investment among all, supporting H2b; While the influence of emotion on transform IT percentage is found positive in results, it is nonsignificant, failing to support H2c. Again, the overall trend of IT signal types shifting supports $\mathrm{H} 2$.

Hypothesis 3 argues that positive management emotion will promote firm's propensity of strategic IT investment different from industry's dominant IT strategic roles. Both negative binomial analysis and multivariate analysis were conducted to examine cross industry differences on the influences of emotions on the count/number and the percentage of strategic IT investments respectively. Those analysis are complementary to each other in providing a full picture of the influence of emotion across industries.

Results (Table 2) suggest there are significant interactions between management emotion and industry. To facilitate understanding the interactions, we provide a set of plots (Figures 2-4 below) organized by industry. To simplify visualization, Data was separated into two groups (high/more positive versus. Low/less positive emotion) based on mean-split of emotion scores.

As Figure 2 shows, despite being dominant industry role in metal industry, automate IT decreases with high emotion in terms of both signal volume and percentage among all signals. In contrast, Informate IT, increases 
with high emotion, while transform IT barely changes, in both signal volumes and proportion among all signals. In financial industry (Figure 3), high emotion increase the volumes of all strategic IT signals but the proportion of transform IT is increased more than that of informate IT-its dominant industry role-while automate IT is losing its weight. Finally, Figure 4 suggests that in retail industry, automate IT increases significantly with high emotion in both signal volumes and proportion among all signals, while transform IT —its dominant industry role-only slightly improves on signal volumes and barely changes on proportion among all IT signals. Note that informate IT in retail industry is declining in both its signal volumes and proportion. Overall, in all three industries, positive emotion moved firms' strategic IT investment away from industry dominant IT roles. H3 is supported.

Table 1. Results of Negative Binomial Analyses (H1a-c) and of Multivariate Analyses (H2a-C)

\begin{tabular}{|c|c|c|c|c|c|c|}
\hline Variable & $\begin{array}{l}\text { H1a: } \\
\text { Automate IT } \\
\text { (Count) }\end{array}$ & $\begin{array}{l}\text { H1b: } \\
\text { Informate IT } \\
\text { (Count) }\end{array}$ & $\begin{array}{l}\text { H1c: } \\
\text { Transform IT } \\
\text { (Count) }\end{array}$ & $\begin{array}{l}\text { H2a: } \\
\text { Automate IT } \\
\text { (Percentage) }\end{array}$ & $\begin{array}{l}\text { H2b: } \\
\text { Informate IT } \\
\text { (Percentage) }\end{array}$ & $\begin{array}{l}\text { H2c: } \\
\text { Transform IT } \\
\text { (Percentage) }\end{array}$ \\
\hline Emotion & $0.118^{*}$ & $0.314^{* *}$ & 0.203 & $-0.168 *$ & $0.153 *$ & 0.132 \\
\hline Industry=Financial & $-0.885 * * *$ & $-1.967 * * *$ & -0.328 & $0.619 * *$ & $-1.337 * * *$ & 0.162 \\
\hline Industry=Metal & $-1.597 * * *$ & $-3.118 * * *$ & $-1.872 * *$ & $0.993 * * *$ & $-1.009 * * *$ & $-0.485^{*}$ \\
\hline Industry=Retail & \multicolumn{6}{|c|}{0 (Comparison base group) } \\
\hline Return on asset & -0.015 & 0.168 & 0.190 & -0.027 & 0.053 & 0.003 \\
\hline $\begin{array}{l}\text { Return on } \\
\text { investment }\end{array}$ & -0.057 & 0.132 & 0.861 & -0.010 & 0.021 & -0.008 \\
\hline Equity per share & 0.055 & 0.064 & 0.916 & -0.030 & 0.002 & 0.029 \\
\hline $\begin{array}{l}\text { Information } \\
\text { interactivity }\end{array}$ & $0.172 * *$ & $0.284 *$ & 0.161 & $-0.233^{*}$ & $0.221 *$ & 0.165 \\
\hline Debt-to-equity & -0.018 & -0.003 & 0.969 & -0.004 & 0.010 & -0.007 \\
\hline Torbin's Q & $0.104 *$ & 0.072 & 0.852 & 0.091 & -0.061 & -0.047 \\
\hline Firm Size & 0.013 & $-0.633 * * *$ & 0.142 & $0.397 * * *$ & $-0.484 * * *$ & -0.145 \\
\hline $\begin{array}{l}\text { Hypothesis } \\
\text { Supported or Not }\end{array}$ & Supported & Supported & Not supported & Supported & Supported & Not supported \\
\hline
\end{tabular}

$*: p<0.05 ; * *: p<0.01 ; * * *: p<0.001$

Table 2. Results of Negative Binomial (H3 and Count DV) and of Multivariate Analyses (H3 and Percentage DV)

\begin{tabular}{|c|c|c|c|c|c|c|}
\hline Variable & $\begin{array}{l}\text { Automate } \\
\text { IT (Count) }\end{array}$ & $\begin{array}{l}\text { Informate } \\
\text { IT (Count) }\end{array}$ & $\begin{array}{l}\text { Transform } \\
\text { IT (Count) }\end{array}$ & $\begin{array}{l}\text { Automate IT } \\
\text { (Percentage) }\end{array}$ & $\begin{array}{l}\text { Informate IT } \\
\text { (Percentage) }\end{array}$ & $\begin{array}{l}\text { Transform IT } \\
\text { (Percentage) }\end{array}$ \\
\hline Emotion & $0.178 * *$ & 0.187 & 0.236 & -0.086 & 0.082 & 0.051 \\
\hline Industry=Financial & $-0.882 * * *$ & $-2.287 * * *$ & $-0.915 * * *$ & $0.660 * *$ & $-1.347^{* * *}$ & 0.100 \\
\hline Industry=Metal & $-1.643 * * *$ & $-3.192 * * *$ & $-3.273 * * *$ & $1.054 * * *$ & $-0.994 * * *$ & $-0.604 * *$ \\
\hline Industry=Retail & \multicolumn{6}{|c|}{0 (Comparison base group) } \\
\hline Return on asset & -0.009 & 0.161 & 0.362 & -0.017 & 0.048 & -0.010 \\
\hline Return on investment & -0.055 & 0.134 & -0.040 & -0.005 & 0.018 & -0.013 \\
\hline Equity per share & 0.053 & 0.048 & 0.033 & -0.019 & 0.001 & 0.010 \\
\hline Information interactivity & $0.201 * *$ & 0.190 & $0.684 * * *$ & $-0.247^{*}$ & $0.202^{*}$ & $0.204 *$ \\
\hline Debt-to-equity & -0.017 & 0.000 & 0.040 & -0.015 & 0.013 & 0.011 \\
\hline Torbin's Q & $0.097 *$ & 0.019 & -0.155 & 0.145 & -0.065 & -0.137 \\
\hline Firm Size & -0.012 & $-0.579 * * *$ & $-0.689 * * *$ & $0.413 * * *$ & $-0.468 * * *$ & -0.187 \\
\hline Emotion* Financial Industry & -0.049 & $0.724 *$ & 0.669 & $-0.419 *$ & 0.120 & $0.623 * *$ \\
\hline Emotion*Metal Industry & $-0.246 *$ & 0.382 & -0.855 & 0.054 & 0.128 & -0.201 \\
\hline Emotion*Retail Industry & \multicolumn{6}{|c|}{0 (Comparison base group) } \\
\hline
\end{tabular}

$*: p<0.05 ; * *: p<0.01 ; * * *: p<0.001$ 

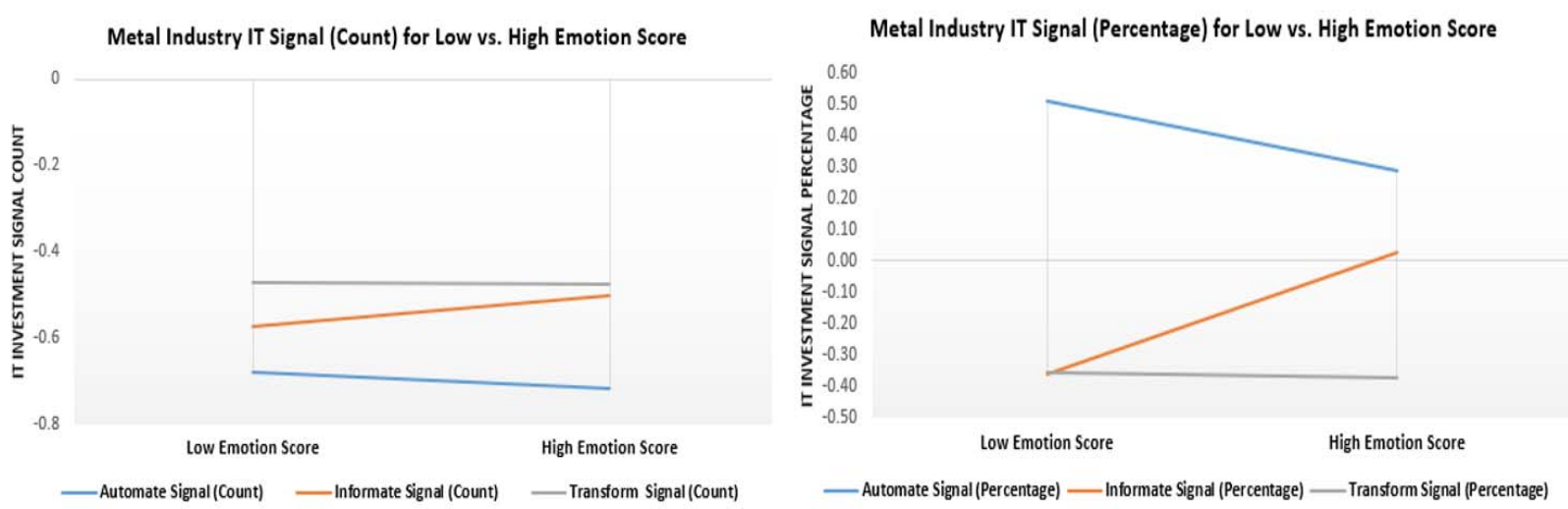

Figure 2. Metal industry IT signal (count \& percentage) for low and high emotion score
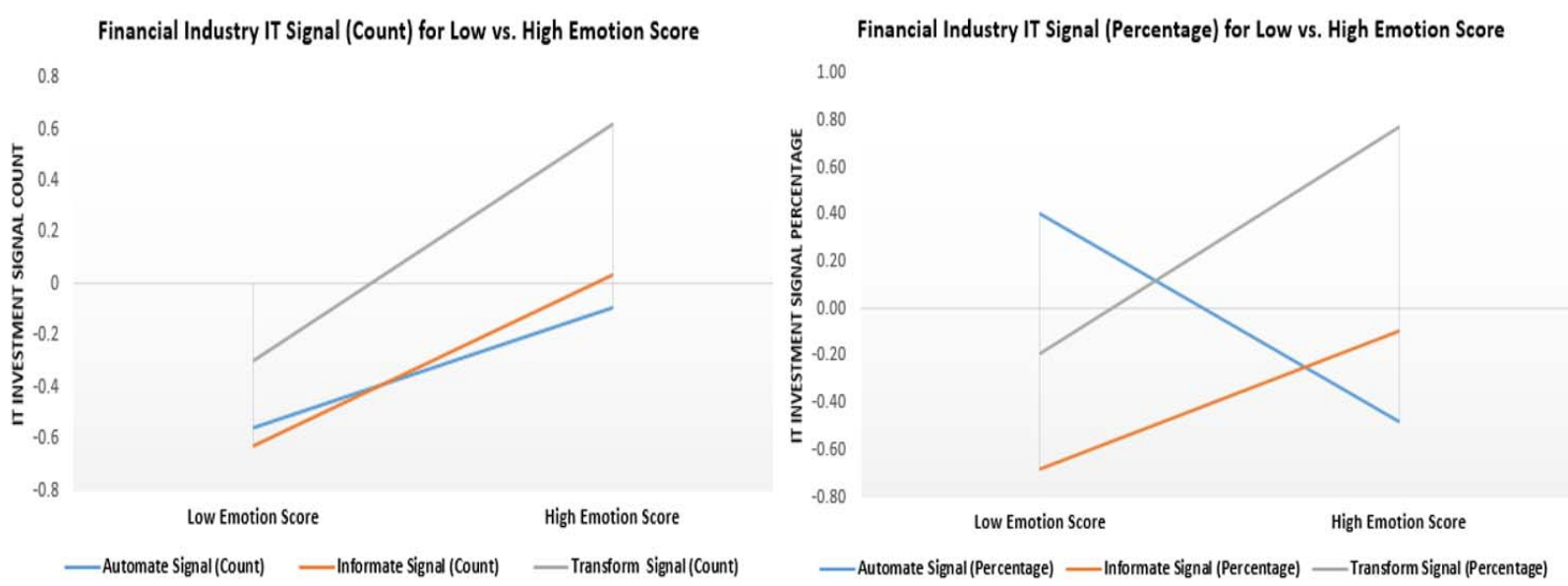

Figure 3. Financial industry IT signal (count \& percentage) for low and high emotion score
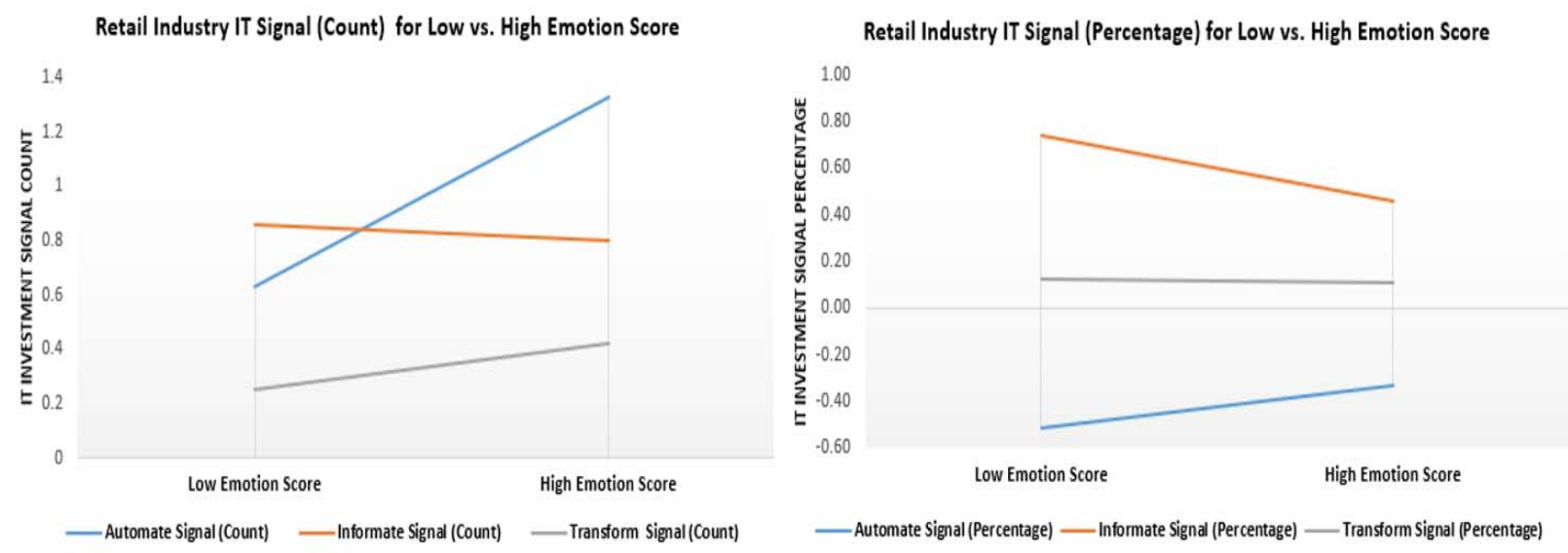

Figure 4. Retail industry IT signal (count \& percentage) for low and high emotion score 
Some control variables are found to have significant impacts. First, information interactivity significantly increases the volumes of strategic IT signals. Firms who are active in communicating with stakeholders appear to release more strategic IT signals. The proportion of automate IT signals, however, decreases for firms with more information interactivity, while those of informate and transform IT increase, suggesting firms with more information activities are more likely to release informate and transform IT signals. Firm size is also found to improve automate IT signals proportion among all strategic IT signals but reduce the volume and proportion of informate signals and the volume of transform signals. Larger firm size can increase organizational inertia and let informate and transform IT investment more challenge to take on.

\section{Discussion}

Due to the assumption of firms' rational decision maker, the existing IS literature has, to a large extent, focus on the expected (normal) return of IT strategic investment and received mixed results on IT payoff [2, 6]. This study considered the irrational characteristics of firms' decision making and is the first investigation of management emotion's role in firms' propensity of strategic IT investment.

Our results show that as management emotion becomes more positive, the confidence and ambitions in strategic IT investment appear improved, and firms tend to spend more resources on strategic IT investments for long term benefits, knowing those investments can be potentially risky and costly. Furthermore, while investment on all strategic IT are increased with positive emotion, firms tend to give more weights to informate IT and/or transform IT than automate IT in their overall IT investment portfolio. The logic behind those tendencies is likely that positive emotion stimulates firms' more aggressive investment in strategic IT but with priority for more advanced IT investments (i.e., informate and transform), because automate IT is often perceived as less innovative and disruptive to existing business/markets.

Additionally, our results indicate that under positive emotion, firms show tendencies to break away from dominant industry strategic IT roles in their strategic IT investments. This finding is an interesting observation because dominant industry strategic IT roles represent legitimate peer group behavior pattern in each unique industry context. Distancing from the "herd" is obviously not a "safe" IT investment bet and requires management to think "out of box" and overcome organizational inertia, which can be difficult without positive management emotion.
This paper contributes to the IS literature by illustrating the importance of understanding the role of management emotion in firm's strategic IT investment propensity. Such influence is especially important for those advanced IT investments and for IT investments that deviate from dominant industry strategic IT roles.

This paper provides implications for investors, management and academia. Signaling firms' propensity of strategic IT investment are often perceived positively by financial markets as investors presume strategic IT, especially those breaking away from industry norm, that can potentially bring in above normal return. However, before welcoming and reacting positively to those messages, investors need to be cautious if high risk strategic IT investment are made with management emotion. By examining firms' propensity of strategic IT investment under emotion, this paper's findings provide empirical evidences for investors to predict the direction of firms' strategic IT investment under emotions and give them grounds to take a second look at firms' strategic IT signals before reacting.

For firms' management, findings of this paper remind them that emotions can influence their strategic IT decisions subconsciously. Therefore, "cooling down" and seeking "second eye" before final decisions can help firms to reach more realistic and successful strategic IT investment.

For academia, this paper's findings cast light on human irrationality in strategic IT investment decision making and give a call for further research on the role of management emotion in strategic IT investment.

This paper is not without limitations. One limitation is regarding the selection of focal industries. Our selection is based on Zmud et al [31], to be consistent with existing literature. Future research may include additional industries. Another future research direction is to expand the time frame to include post- 2015 fiscal years; although the emotion scores could be easily calculated by the software, extending the time frame would require extensive manual coding of IT signals embedded in post-2015 annual reports.

\section{Conclusion}

This paper investigates the impacts of management emotion on the tendency of firms to engage in different strategic roles of IT. Findings show that positive management emotion promotes firm's propensity of strategic IT investments, with priority on informate and/or transform IT, and strategic IT different from industry's dominant IT strategic role. Understanding the roles of management emotion in shaping firm's propensity of strategic IT investment helps investors to predict the tendency of firms to engage in different 
strategic roles of IT and extends existing IS business value research.

\section{References}

1. Huang, J.Y., J.C. Shieh, and Y.-C. Kao, Starting points for a new researcher in behavioral finance. International Journal of Managerial Finance, 2016. 12(1): p. 92-103.

2. Brynjolfsson, E., The productivity paradox of information technology. Communications of the ACM, 1993. 36(12): p. 66-77.

3. Robey, D. and M.-C. Boudreau, Accounting for the contradictory organizational consequences of information technology: Theoretical directions and methodological implications. Information systems research, 1999. 10(2): p. 167-185.

4. Devaraj, S. and R. Kohli, Information technology payoff in the health-care industry: a longitudinal study. Journal of management information systems, 2000. 16(4): p. 41-67.

5. Kohli, R. and S. Devaraj, Measuring information technology payoff: A meta-analysis of structural variables in firm-level empirical research. Information systems research, 2003. 14(2): p. 127145.

6. Brav, A. and J.B. Heaton, Competing theories of financial anomalies. The Review of Financial Studies, 2002. 15(2): p. 575-606.

7. Frijda, N.H., The emotions. 1986: Cambridge University Press.

8. De Dreu, C.K., et al., Origins and consequences of emotions in organizational teams. Emotions at work: Theory, research and applications in management, 2001: p. 199-217.

9. Kelly, J.R. and S.G. Barsade, Mood and emotions in small groups and work teams. Organizational behavior and human decision processes, 2001. 86(1): p. 99-130.

10. Lewis, M., J.M. Haviland-Jones, and L.F. Barrett, Handbook of emotions. 2010: Guilford Press.

11. Carver, C., Pleasure as a sign you can attend to something else: Placing positive feelings within a general model of affect. Cognition and Emotion, 2003. 17(2): p. 241-261.

12. Isen, A.M. and R. Patrick, The effect of positive feelings on risk taking: When the chips are down. Organizational behavior and human performance, 1983. 31(2): p. 194-202.

13. Kida, T.E., K.K. Moreno, and J.F. Smith, The influence of affect on managers' capital-budgeting decisions. Contemporary Accounting Research, 2001. 18(3): p. 477-494.

14. Tversky, A. and D. Kahneman, Judgment under uncertainty: Heuristics and biases. science, 1974. 185(4157): p. 1124-1131.

15. Mackie, D.M. and L.T. Worth, Feeling good, but not thinking straight: The impact of positive mood on persuasion. 1991.
16. Bless, H., et al., Mood and the use of scripts: Does a happy mood really lead to mindlessness? Journal of personality and social psychology, 1996. 71(4): p. 665.

17. Schwarz, N. and H. Bless, Constructing reality and its alternatives: An inclusion/exclusion model of assimilation and contrast effects in social judgment. 1991.

18. Elsbach, K.D. and P.S. Barr, The effects of mood on individuals' use of structured decision protocols. Organization Science, 1999. 10(2): p. 181-198.

19. Prechter Jr, R.R., Unconscious herding behavior as the psychological basis of financial market trends and patterns. The Journal of Psychology and Financial Markets, 2001. 2(3): p. 120-125.

20. Abrahamson, E., Managerial fads and fashions: The diffusion and rejection of innovations. Academy of management review, 1991. 16(3): p. 586-612.

21. Sun, H., A longitudinal study of herd behavior in the adoption and continued use of technology. MIS Quarterly, 2013. 37(4).

22. Estrada, C.A., A.M. Isen, and M.J. Young, Positive affect facilitates integration of information and decreases anchoring in reasoning among physicians. Organizational behavior and human decision processes, 1997. 72(1): p. 117-135.

23. Isen, A.M., Positive affect and decision making. Handbook of Emotions. M. Lewis and JM Haviland-Jones, 2000, New York, The Guilford Press.

24. Davis, M., Understanding the relationship between mood and creativity: A meta-analysis. Organizational Behavior and Human Decision Processes Mis Quarterly, 2009. 25(1): p. 43-70.

25. Foo, M., M. Uy, and R. Baron, How do feelings influence effort? An empirical study of entrepreneurs' affect and venture effort. Journal of Applied Psychology 2009. 94(4): p. 1086-1094.

26. Grichnik, D., A. Smeja, and I. Welpe, The importance of being emotional: How do emotions affect entrepreneurial opportunity evaluation and exploitation? Journal of Economic Behavior \& Organization, 2010. 76(1): p. 15-29.

27. Baron, R.A., The role of affect in the entrepreneurial process. Academy of management Review, 2008. 33(2): p. 328-340.

28. Armstrong, C.P. and V. Sambamurthy, Information Technology Assimilation in Firms: The Influence of Senior Leadership and IT Infrastructures. Information Systems Research, 1999. 10(4): p. 304-327.

29. Aral, S. and P. Weill, IT Assets, Organizational Capabilities, and Firm Performance: How Resource Allocations and Organizational Differences Explain Performance Variation. Organization Science, 2007. 18(5): p. 763-780.

30. Dehning, B., V.J. Richardson, and R.W. Zmud, The Value Relevance of Announcements of Transformational Information Technology 
Investments. MIS Quarterly, 2003. 27(4): p. 637656.

31. Zmud, R.W., et al., Systematic Differences in Firm's Information Technology Signaling: Implications for Research Design. Journal of the Association for Information Systems, 2010. 11(3): p. 149-181.

32. Bettman, J.R. and B.A. Weitz, Attributions in the Board Room: Causal Reasoning in Corporate Annual Reports. Administrative Science Quarterly, 1983. 28(2): p. 165-183.

33. Lev, B., Information Disclosure Strategy. California Management Review, 1992. 34(4).

34. Arndt, M. and B. Bigelow, Presenting structural innovation in an institutional environment: Hospitals' use of impression management. Administrative Science Quarterly, 2000(45): p.: 494-522.

35. Elsbach , K.D., Managing organizational legitimacy in the California cattle industry: The construction and effectiveness of verbal accounts. Administrative Science Quarterly, 1994. 39(1): p. 57-88.

36. Dos Santos, B.L., K. Peffers, and D.C. Mauer, The Impact of Information Technology Investment Announcements on the Market Value of the Firm. Information Systems Research, 1993. 4(1): p. 1-24.

37. Im, K.S., K.E. Dow, and V. Grover, Research report: a reexamination of IT investment and the market value of the firm-an event study methodology. Information Systems Research, 2001. 12(1): p. 103-117.

38. Chatterjee, D., C. Pacini, and V. Sambamurthy, The shareholder-wealth and trading-volume effects of information-technology infrastructure investments. Journal of Management Information Systems, 2002. 19(2): p. 7-42.

39. Loughran, T. and B. McDonald, Textual analysis in accounting and finance: A survey. Journal of Accounting Research, 2016. 54(4): p. 1187-1230.

40. Kearney, C. and S. Liu, Textual sentiment in finance: A survey of methods and models. International Review of Financial Analysis, 2014. 33: p. 171-185.

41. Li, F., Do Stock Market Investors Understand the Risk Sentiment of Corporate Annual Reports? 2006.

42. Tanriverdi, $\mathrm{H}$. and T.W. Ruefli, The role of information technology in risk/return relations of firms. Journal of the Association for Information Systems, 2004. 5(11-12): p. 421-447.

43. Piccoli, G. and B. Ives, IT-dependent strategic initiatives and sustained competitive advantage: a review and synthesis of the literature. MIS quarterly, 2005. 29(4): p. 747-776.

44. Bower, G.H., Mood congruity of social judgments. Emotion and social judgments, 1991. 31: p. 53.

45. Garcia-Marques, T., et al., Positivity can cue familiarity. Personality and Social Psychology Bulletin, 2004. 30(5): p. 585-593.
46. Venkatraman, N. and J. Henderson, Strategic alignment: leveraging information technology for transforming organizations. IBM systems journal, 1993. 32(1): p. 4-16.

47. Hughes, A. and M.S.S. Morton, The transforming power of complementary assets. MIT Sloan Management Review, 2006. 47(4): p. 50.

48. Kumar, K. and J. Van Hillegersberg, ERP experiences and evolution. Communications of the ACM, 2000. 43(4): p. 22-22.

49. Kobelsky, K.W., et al., Determinants and consequences of firm information technology budgets. The Accounting Review, 2008. 83(4): p. 957-995.

50. Galliers, R.D. and W.R. Baets, Information technology and organizational transformation: innovation for the 21st century organization. 1998: John Wiley \& Sons, Inc.

51. Fredrickson, B.L., The role of positive emotions in positive psychology: The broaden-and-build theory of positive emotions. American psychologist, 2001. 56(3): p. 218.

52. Fredrickson, B.L., The broaden-and-build theory of positive emotions. Philosophical Transactions of the Royal Society of London. Series B: Biological Sciences, 2004. 359(1449): p. 1367-1377.

53. Fredrickson, B.L. and C. Branigan, Positive emotions broaden the scope of attention and thought-action repertoires. Cognition \& emotion, 2005. 19(3): p. 313-332.

54. Gasper, K. and G.L. Clore, Attending to the big picture: Mood and global versus local processing of visual information. Psychological science, 2002. 13(1): p. 34-40.

55. Hayton, J.C. and M. Cholakova, The role of affect in the creation and intentional pursuit of entrepreneurial ideas. Entrepreneurship theory and practice, 2012. 36(1): p. 41-67.

56. Denzin, N.K., The Research Act: A Theoretical Introduction to Sociological Methods. 1989, Englewood Cliffs,NJ: Prentice-Hall.

57. Chatterjee, D., V.J. Richardson, and R.W. Zmud, Examining the shareholder wealth effects of announcements of newly created CIO positions. Mis Quarterly, 2001. 25(1): p. 43-70.

58. Lloyd, L., D. Kechagias, and S. Skiena, Lydia: A System for Large-Scale News Analysis, in String Processing and Information Retrieval, C. M. and N. G., Editors. 2005, Springer: Berlin, Heidelberg.

59. Landis , J.R. and G.G. Koch, An Application of Hierarchical Kappa-type Statistics in the Assessment of Majority Agreement among Multiple Observers. Biometrics, 1977. 33(2): p. 363-374.

60. Calantone, R.J. and K.E. Schatzel, Strategic foretelling: Communication-based antecedents of a firm's propensity to preannounce. Journal of Marketing, 2000. 64(1): p. 17-30.

61. Nelder, J.A. and R.W.M. Wedderburn, Generalized linear models. Journal of the Royal Statistical Society, 1972. 135(3): p. 370-384. 